\title{
ЗАЛЕЖНІСТЬ ВІДГОДІВЕЛЬНИХ ЯКОСТЕЙ СВИНЕЙ ДАНСЬКОГО ПОХОДЖЕННЯ ВІД ТИПУ ГОДІВЛІ
}

\author{
Михалко Олександр Григорович \\ аспірант спец. 204 ТВППТ \\ Сумський національний аграрний університет \\ ORCID ID: 0000-0002-0736-2296/ G-2305-2018 \\ Email: snau.cz@ukr.net
}

Метою статті було дослідити залежність відгодівельних якостей поголів'я свиней данського походження від тиnу їх годівлі. 3 метою визначення впливу типу кормів на результати відгодівлі свиней був проведений наукововиробничий дослід на базі індустріального свинокомплексу в умовах Центрального степу України, по завершенню якого отримані дані були узагальнені, проаналізовані та описані в даній науковій роботі. Відгодівля молодняку свиней здійснювалась у двох технологічних групах по 195 голів в приміщеннях відгодівельних цехів одного підприємства, де були ідентичні умови їх утримання за виключенням типу кормосумішей в раціонах. Свині контрольної групи відгодовувались сухим кормом, а свині дослідної - рідким. Початкова середня жива маса та вік при постановиі були однаковими у тварин обох груп, однак, по завершенню періоду відгодівлі у 88-денному віці свині, що споживали рідкий корм, достовірно переважали однолітків на сухому типі корму на 6,9 ка або 6,1\% (p<0,001). Також встановлено, що показники інтенсивності росту були вищими у тварин дослідної групи на 87,1 г або 9,4\% - за середньодобовим приростом, на 8,3 кг або 8,5\% - за абсолютним приростом, на 4,0\% - за відносним приростом. Достовірно швидше на 5,6 днів або 3,8\% досягали маси в 100 ка свині на відгодівлі рідкими кормами, відносно аналогів на відгодівлі сухими. Не виявлено вірогідного впливу типу кормів на коефіцієнт конверсії корму у поголів'я обох груп. Дослідження відгодівельних якостей свиней за комплексом відгодівельних якостей, розрахованих з допомогою оціночного індексу показало, що тварини за використання рідких кормів набрали вищу кількість балів на 6,1 або 17,8\% відносно аналогів, яким давали сухі корми. Таким чином, відгодівля молодняку свиней данського походження за використання рідкого типу годівлі є більш ефектииною та дає більш високі результати за коротший термін при однакових витратах корму порівняно із відгодівлею сухим кормом.

Ключові слова: відгодівля свиней, відгодівельні якості, тип корму, рідкі та сухі корми, тип годівлі

DOI: https://doi.org/10.32845/bsnau.lvst.2021.4.17

Висока конкуренція у виробництві свинини вимагає підвищеної уваги до технології та техніки годівлі. Оскільки вартість кормів становить значну частину від загальних витрат в сучасному свинарстві, то ефективність використання кормів має величезний вплив на прибутковість виробників. Тому одним з найважливіших питань $є$ найбільш раціональне використання кормів [12].

Тим більше, із численних фракторів зовнішнього середовища, які впливають на індивідуальний розвиток тварин, найбільш істотним $є$ фактор годівлі. Годівля - основний фактор, що забезпечує ріст і розвиток організму свиней, їх продуктивність, адаптацію до впливу зовнішнього середовища і в кінцевому підсумку - здійснює визначальний вплив на якість туш і хімічний склад тканин [8].

Поряд з повноцінністю раціону важливу роль у відгодівлі свиней та зниженні собівартості свинини відіграє техніка підготовки кормів до згодовування.

Типи годівлі свиней в залежності від співвідношення сухого корму і води згідно повідомленнями [3] поділяються на рідкі, вологі, розсипчасті і сухі.

Встановлено, що свині віддають перевагу вологим кормам у порівнянні з сухими і рідкими [6, 23].

Донедавна більшість свинарських підприємств віддавали перевагу саме методу сухої годівлі. Вважалося, що впровадження такого типу годівлі пов'язане із нижчими витратами на установку і обслуговування устаткування, і забезпечувало кращий санітарно-гігієнічний стан приміщень [9].

Однак, останнім часом системи рідкої годівлі стали більш популярними у багатьох європейських країнах. Оскільки їх використання дозволяє застосовувати відходи та вторинні продукти харчової та мікробіологічної промисловості [36].

Як сухий, так і рідкий тип годівлі може підтримувати ріст свиней, однак, який з них краще допоможе реалізувати генетично-обумовлену скоростиглість, дати кращі середньодобові прирості, вищу конверсію корму у поголів'я для тієї чи іншої породи - питання відкрите [19].

Дослідженнями встановлено, що основними критеріями ефективності виробництва високоякісної свинини є збільшення показників відтворювальних якостей тварин основного стада, підвищення відгодівельних та м'ясних якостей їх потомства [10].

Залежність відгодівельних якостей свиней від типу їх годівлі вивчалась у багатьох дослідах, де науковці відзначали як позитивний, так і негативний вплив останнього.

Так, на думку іноземних науковців [29], у свиней, котрих годували рідкими кормами був більший показник $(p<0,01)$ середньодобового приросту та середньодобового споживання корму та гірше співвідношення приріст:корм, ніж у свиней, що відгодовувались сухим кормом.

Однак, на противагу вищесказаному існує думка [38], що споживання рідкого типу кормів навпаки покращує співвідношення приріст:корм.

B.J. Chae [17] доводить, що завдяки споживанню рідких кормів у свиней спостерігалося зростання споживання корму та підвищення швидкості росту відносно тих, які споживали сухий корм.

Подібне твердження висунув і J.S. Moon [28], вказавши, що протягом періоду відгодівлі у свиней, яких годували рідкими кормами, був вищим показник середньодобового приросту та коефіцієнт конверсії корму, ніж у тих, що году- 
вались лише сухими кормами $(p<0,05)$.

Вітчизняними дослідниками [2] встановлено, що поросята, які дорощувались за рідкого мультифазного типу годівлі, споживали щодоби більше на 12,4 \% корму, мали вищі на 7,0 та 18,3 \% середньодобові прирости, на 7,3 і 18,4 $\%$ абсолютні прирости, досягаючи при цьому маси в 100 кг на 7,8 днів раніше, ніж за використання сухого типу [5].

На підвищення средньодобових приростів за рідкого типу годівлі вказує і R.C. Sulabo [37]. Аналогічні висновки отримав також D. Hurst [21], , який повідомив, що свині на відгодівлі за рідкого типу кормів мали вищий $(p<0,05)$ середньодобовий приріст та швидкість росту нежирних тканин порівняно з поголів'ям, що споживало сухий корм, але не відрізнялось за коефріцієнтом конверсії корму. Однак, в наступному дослідженні [22] автор вказав, що свині, які годувались рідкими кормами, були не тільки важчими $(p<0,05)$, але і демонстрували покращені коефіцієнти конверсії корму порівняно з аналогами на сухій відгодівлі. Ці відмінності у живій вазі пояснювали змінами у вазі та об'ємі шлунка, які також були важчими та більшими у свиней, що годувались рідкими кормами $(p<0,05)$.

R. Buragohain [15] вказує, що витрати корму на 1 кг приросту маси тіла були значно меншими у свиней на рідкому типі годівлі відносно тих, що відгодовувались сухими кормами $(p<0,05)$.

Проте, в результатах іншого досліду [25] продемонстровано, що хоча рівень споживання корму та середньодобовий приріст були вищими у свиней на рідкому типі годівлі, однак, коефіцієнт конверсії корму кращим був у свиней на сухому кормі.

Підвищення коефіцієнта конверсії корму розглядається як найважливіший елемент ресурсозберігаючої технології. Повноцінна годівля всіх груп свиней племінного і товарного напряму в поєднанні із селекційною роботою сприяє зниженню витрат концентрованих кормів на виробництво одиниці продукції й отриманню до 90\% свинини м'ясної кондиції [4].

Проведений [30] аналіз показав, що свині, яких годували за допомогою рідкого корму, справді мали підвищений темп росту, споживання корму, кінцеву масу тіла та вагу туші. Однак такі свині, відкладали більше жиру та мали менший відсоток нежирного м'яса, ніж ті, яких годували звичайними сухими кормами. Частково дану думку доповнює інше повідомлення [31], де наголошується, що маса туші свиней, які утримувались на відгодівлі за рідкого корму достовірно $(p<0,001)$ переважала масу туші аналогів, які споживали сухий корм. Подібні дослідження [18] показали, що показники туші свиней, яким пропонували сухий корм, були на 8\% кращими порівняно зі свинями, які споживали рідкі корми. В той же час коефіцієнт конверсії корму туш свиней, які відгодовувались на сухому кормі, також був значно вищим.

Одночасно існують дослідження ряду авторів [24, 25], які не встановлюють суттєвої різниці за показниками відгодівельних якостей у свиней за рідкого та сухого типу годівлі.

Також в окремих дослідженнях [34] доведено, що за показниками коефіцієнта конверсії корму та енергії росту відсутні достовірні відмінності між свинями на відгодівлі рідкими та сухими кормами.

Згідно сучасних публікацій [20] коефріцієнт конверсії корму, як правило, був нижчим у свиней, яких годували рідкими кормами, що додатково вказує на збільшення витрат корму при подачі рідини.

Також існує дослідження [13] впливу систем подачі корму на стан здоров'я поголів'я свиней, який повідомляє про достовірно кращий санітарний стан приміщення для відгодівлі за рахунок зменшення пилу в атмосфері і як наслідок - нижчого бактеріального забруднення при використанні саме рідких кормів.

Однак інші автори [11] відзначають підвищену вологість у тваринницьких приміщеннях при використанні рідкого типу годівлі, що негативно впливає на тварин (особливо у зимовий період) та створює додаткове навантаження на роботу системи мікроклімату свинарника

У багатьох дослідженнях відзначається як позитивний, так і негативний вплив рідкого типу годівлі на процес бактеріального забруднення кормів та подальший їх вплив на здоров'я свиней. Так деякі джерела [26] доводять, що молочнокислі бактерії, які в природі трапляються на зернах злаків, розмножуються у вологій суміші та роблять корм більш кислим. Так в наведених матеріалах вказано, що подібний процес консервування відбувається в системах рідинного харчування. Це корисно, оскільки молочнокислі бактерії запобігають розмноженню інших шкідливих бактерій у кормі. Дослідження [14] показали, що годування рідиною зменшує захворюваність на сальмонели.

Хоча C.A. Plumed-Ferrer [35] було доведено, що ферментація рідкої їжі молочнокислими бактеріями покращує якість кормів і корисна для здоров'я тварин. Однак, на його погляд, на спонтанне бродіння не можна покластися, щоб забезпечити безпечний корм, тому в деяких випадках заквашені рідкі корми виявляються небезпечними для свиней і врешті-решт впливають на безпеку споживачів. Автор доводить, що рідке годування іноді пов'язане з розвитком таких захворювань, як синдром гемораргічного кишечника, перекручення шлунка, шлунково-кишковий тракт та виразка шлунка. Як наслідок свині, які зазнали впливу патогенів, реагують зниженим споживанням корму і, отже, призводять до поганого росту. Короткочасне і довгострокове запалення викликає роздратування шлунково-кишкового тракту і знижує відкладення білка, додатково обмежуючи засвоєння поживних речовин для росту [27].

В працях інших науковців [32] вказано, що часто виникають загрози розповсюдження патогенної мікрофрлори при порушеннях режимів очищення систем трубопроводів через те, що у рідких кормах відбувається значний ступінь спонтанного бродіння, що негативно впливає на харчові якості.

3 точки зору добробуту тварин [39] вважається більш комфортною годівля свиней сухими кормами, оскільки, свині, яким пропонували рідкі корми, виражали небажану агресивну поведінку в стаді та неспокій перед і після годівлі.

На противагу автор інших досліджень [11] вказує, що при використанні систем подачі сухого корму 18-25\% тварин знаходяться в постійному русі між годівницею та напувалкою, заважаючи відпочинку інших, а втрати корму при цьому досягають 3-9\%.

Згідно опублікованих праць [16] свині, споживаючи рідкий корм, харчувались швидше, (52,1-118,9 г/хв.) та мали значно більшу кінцеву вагу тіла $(16 \%)$, середньодобовий приріст (27\%), вагу туші (16\%), вміст м'яса в туші (14\%), ніж 
свині, які споживаючи сухий корм, їли повільно (12,6 до 38,2 Г/ХВ.).

Отже, дослідженню впливу типу годівлі на відгодівельні якості свиней присвячена велика кількість наукових публікацій, однак, результати досліджень не є одностайними у багатьох аспектах даної теми.

Таким чином, порівняльне вивчення відгодівельних якостей свиней за різної системи їх відгодівлі є досить актуальним.

Метою роботи є вибір напрямів удосконалення та актуальних векторів розвитку технологічних особливостей відгодівлі свиней з урахуванням встановлених проблем

Матеріали і методи досліджень. Для досягнення цілей дослідження був проведений експеримент щодо вивчення відгодівельних якостей свиней данського походження під впливом різних типів кормів, що утримувались двома групами по 195 голів терміном 88 днів в цехах відгодівлі підприємства ТОВ «АГРОІНД» Дніпропетровської області, Дніпровського району за використання двох технологічно відмінних типів годівлі, однак, за інших рівних умов утримання впродовж вказаного часу (табл. 1).

Схема досліду

\begin{tabular}{|c|c|c|c|}
\hline Група тварин & Кількість голів в групі & Вік при постановці & Тип годівлі \\
\hline І (контрольна) & 195 & 70 & Сухий \\
\hline ІІ (дослідна) & 195 & 70 & Рідкий \\
\hline
\end{tabular}

У I (контрольну) групу було включено свиней у віці 7Џ накопичувачів до автомата роздачі корму. До бункера кормоднів, що мали однакову середню живу масу. Поголів'я розмі вого автомату корм надходив у сухому вигляді. Щоб точно щувалось у станках по 50 голів на суцільно щілинній підлозі іф встановити кількість спожитого корму в кожному дослідному щільністю 0,75 м² на 1 голову. Годівля свиней здійснюваласф станку були перекриті шибери подачі суміші, а його подавання за використання сухих кормових сумішей із повнораціонних в годівниці відбувалось шляхом зважування вручну. Корм комбікормів власного виробництва, які зволожувались в кор зволожувався автоматично за допомогою зрошувачів розмімових автоматах американської фірми Hog Slat (рис. 1, п. 1). щених в робочому просторі жолоба кормового автомату. ДовКорм транспортувався за допомогою ланцюгово-шайбовогф жина кормушки дозволяла мати фронт годівлі із розрахунку на транспортера (рис. 2, п. 3) та опусків (рис. 2, п. 2) із бункерів одну голову 0,1 м.

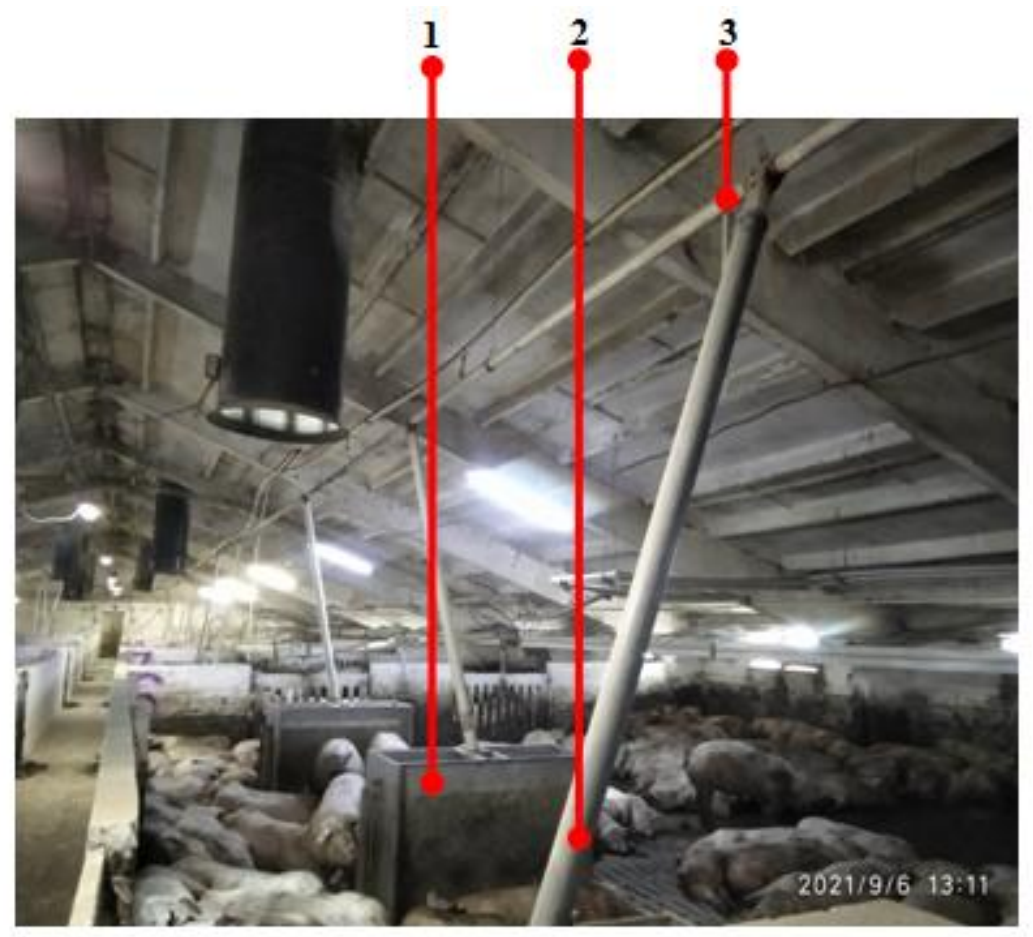

Рuc. 1 Система подачі сухого корму

1 - кормовий автомат, 2 - опуск, 2 - ланцюгово-шайбовий транспортер

Поголів'я II (дослідної групи) було ідентичне за віком середньою живою масою, однак, в процесі відгодівлі спожива ло рідкий корм. Процес приготування рідкої суміші та подаль ша її роздача здійснювалась за використання кормової кухн швейцарської фірми Schauer. Консистенція рідкого корму фо рмувалась у співвідношенні 1 частина повнораціонного збала нсованого корму до 3-х частин води. Корм доводився до готов ності в резервуарах кормокухні способом додавання підкисле ної води до її сухої частини. Перемішана фракція транспорту валась системою трубопроводів (рис.2, п. 2, 3, 5) до годівниць (рис. 1, п. 4) 10-12 разів протягом 24-х годин. Рівень наповненості годівниць контролювався датчиками (рис.1, п. 1), що при неповному поїданні корму тваринами автоматично блокували подачу чергової порції корму, зменшуючи при цьому добову частоту годівлі. Фронт годівлі встановлено 0,18 м на одну голову. Облік корму поданого на кожний окремий станок проводився за допомогою програми кормової кухні. 


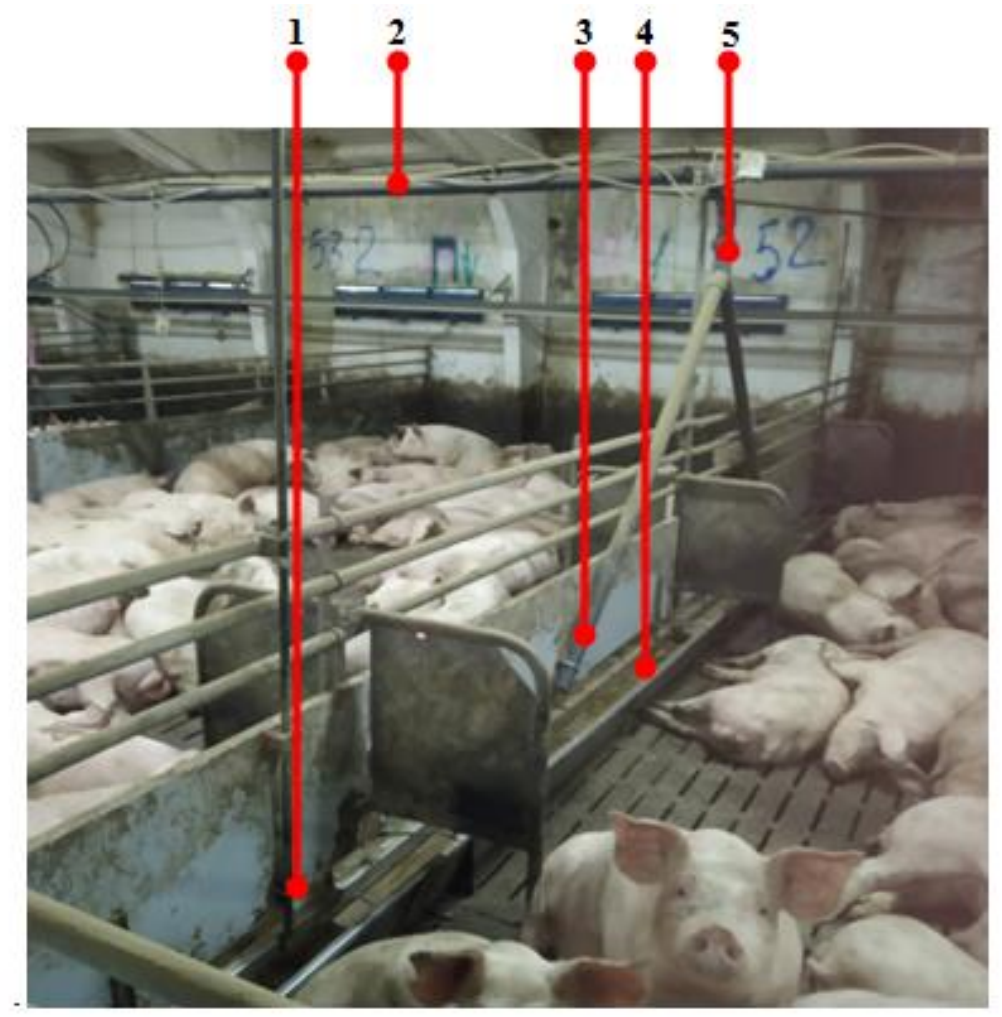

Рис. 2 Система подачі рідкого корму

1 - індикатор наповнюваності, 2 - магістральний трубопровід, 3 - розподільчий трубопровід, 4 - годівниця, 5 - трубопровід

Тварини обох групи свиней були отримані від помісних свиноматок данського ландраса свиноматок $F_{1}$ материнської лінії «Данбред», яких осіменяли спермою кнурів данського дюроку, відповідно до схеми гібридизації свинарського комплексу. Утримання поголів'я як дослідної, так і контрольної груп було аналогічним в підсисний період та період дорощування.

При постановці та при знятті з відгодівлі усі піддослідні свині були індивідуально зважені, що дозволило провести розрахунки показників ї інтенсивності росту, середньодобового споживання та оплати корму.

Вік досягнення живої маси 100 кг визначали за формулою:

$$
\mathrm{X}=\mathrm{B}+\frac{100-\mathrm{m}}{\Pi},
$$

де: $X$ - вік досягнення маси 100 кг, днів;

В - фактичний вік тварин на день останнього зважування, днів; m - фактична маса тварин на день останнього зважування, кГ;

П - середньодобовий приріст тварин за обліковий період, кг [7].

3 метою вивчення відгодівельних якостей свиней було застосовано комплексний індекс відгодівельних якостей за формулою М.Д. Березовського [1]:

$$
\mathrm{I}=\frac{\mathrm{A}^{2}}{\mathrm{~B} * \mathrm{C}},
$$

де: A - валовий приріст за період відгодівлі, кг;

В - кількість діб відгодівлі;

C - витрати корму на 1 кг приросту.

Результати досліду були обраховані біометрично за допомогою прикладних програм Microsoft Office Excel.

Результати досліджень (табл. 2) дали можливість встановити відмінності в показниках відгодівельних якостей свиней обох груп.

Відгодівельні показники свиней за різного типу годівлі, $(n=195)$

Таблиия 2

\begin{tabular}{|l|c|c|}
\hline \multicolumn{1}{|c|}{ Показник } & \multicolumn{2}{|c|}{ Тип годівлі } \\
\cline { 2 - 3 } & $\begin{array}{c}\text { I контрольна група } \\
\text { (сухий тип годівлі) }\end{array}$ & $\begin{array}{c}\text { II дослдн група } \\
\text { (рідкий тип годівлі) }\end{array}$ \\
\hline Середня маса при постановці на відгодівлю, кг & $30,0 \pm 0,21$ & $30,1 \pm 0,24$ \\
\hline Середня маса при знятті з відгодівлі, кг & $112,3 \pm 0,73$ & $119,2 \pm 0,79^{* * *}$ \\
\hline Кількість днів на відгодівлі, діб & 88 & 88 \\
\hline Абсолютний приріст, кг & $82,1 \pm 1,98$ & $89,1 \pm 1,91^{*}$ \\
\hline Середньодобовий приріст, г & $926,0 \pm 8,58$ & $1013,1 \pm 8,59^{* * *}$ \\
\hline Відносний приріст, \% & $115,4 \pm 1,23$ & $119,4 \pm 1,15^{*}$ \\
\hline Витрати корму на 1 кг приросту (конверсія), кг & 2,75 & 2,66 \\
\hline Вік досягнення маси 100 кг, діб & $151,7 \pm 0,72^{* * *}$ & $146,1 \pm 0,91$ \\
\hline Індекс відгодівельних якостей, балів & 27,8 & 33,9 \\
\hline
\end{tabular}

Примітки: ${ }^{*} P>0,95 ;{ }^{* *} P>0,99$ 
На початку відгодівлі достовірної різниці між тваринами за показником середньої маси не встановлено. Проте, по завершенню відгодівлі свині, що споживали рідкий корм мали вірогідно вищі показники середньої маси порівняно із однолітками, утримуваними за використання сухого типу годівлі на 6,9 кг або 6,1\% (p<0,001).

Також встановлено, що свині дослідної групи випереджали аналогів контрольної за показникам абсолюного приросту на 8,3 кг або 8,5\% (p<0,05).

Порівняння показників середньодобового приросту у поголів'я обох піддослідних груп показало достовірно вищий його рівень у свиней вирощуваних за рідкого типу годівлі на $87,1$ г або 9,4\% ( $p<0,001)$.

Дослідження відносного приросту виявило, що вищим він був у свиней, які відгодовувались також на рідкому раціоні на $4,0 \% \quad(p<0,05)$ порівняно з свиньми контрольної групи.

Отже, аналіз інтенсивності росту відгодівельного молодняку протягом досліджуваного періоду показав, що тварини, які утримувались за рідкого раціону достовірно переважали за абсолютними, середньодобовими та відносними приростам аналогів, котрі відгодовувались сухими кормами. Також в результаті досліджень знайдено тенденцію до переважання свиней дослідної групи над однолітками контрольної за показником конверсії корму - на 0,09 кг або 3,3\%. Одночасно, поголів'я, яке отримувало рідкий корм достовірно раніше досягало маси 100 кг - на 5,6 днів або 3,8\% ( $p<0,001)$.

Свині, що утримувались за споживання сухого корму, поступались аналогам, які споживали рідкі кормосуміші на 6,1 балів або 17,8\% за комплексом відгодівельних якостей, розрахованих з допомогою оціночного індексу.

Обговорення результатів дослідження.

Встановлене багатьма дослідниками $[15,17,22,28$, 38] переважання свиней за показником конверсії корму на рідкому типі годівлі не підтверджується результатами наших досліджень. Також не знайшла підтвердження і протилежна думка іноземних авторів [18, 20 25, 29] про покращення конверсії корму при відгодівлі свиней сухими кормами. Однак, відмічаємо, що подібно іншим повідомленням науковців [34] ми дійшли висновку, що за показниками коефіцієнта конверсії корму відсутні будь-які достовірні відмінності між свинями на відгодівлі рідкими та сухими кормосумішами.
Необхідно зауважити, що встановлений нами факт переважання показників інтенсивності росту свиней при відгодівлі рідкими кормами над аналогами, що споживають сухі корми підтверджується як у зарубіжних, так і у вітчизняних наукових працях [2, 16, 21, 25, 28, 29, 37].

Виявлений нами результат, що свині, які споживали рідкий корм, мали вищу середню масу по завершенні відгодівлі відносно однолітків на сухому кормі та швидше досягали маси в 100 кг співпадає з відомими публікаціями [17, 22, 30, 31], які демонструють подібні висновки, проте, суперечить поширеним доводам [24, 25], в яких авторами не знайдено достовірних відмінностей за показниками відгодівельних якостей у поголів'я свиней за різних типів годівлі.

\section{Висновки.}

На основі проведених досліджень встановлено, що свині данського походження за вирощування в умовах індустріального комплексу степової зони України мали вірогідно вищі показники інтенсивності росту при відгодівлі рідкими кормами порівняно з аналогами, що споживали сухий корм. Зокрема вищим був показник середньодобового приросту на 87,1 г або 9,4\%, показник абсолюного приросту на 8,3 кг або $8,5 \%$ та показник відносного приросту на $4,0 \%$ у відгодівельного молодняку за використання саме рідкого типу годівлі.

Також за відгодівлі свиней раціонами із рідким типом корму тварини достовірно швидше досягали живої маси в 100 кг на 5,6 днів або 3,8\% відносно однолітків, що відгодовувались сухими кормосумішами.

Поголів'я, яке споживало сухі корми, мало вірогідно нижчу масу на 6,9 кг або 6,1\% порівняно із свинями на рідкій відгодівлі.

Однак, за показником конверсії корму не знайдено вірогідної різниці між свинями за різних типів годівлі.

За комплексом відгодівельних якостей, розрахованих з допомогою оціночного індексу свині за використання рідких кормів мали вищу оцінку на 6,1 балів або 17,8\%, відносно свинопоголів'я на відгодівлі сухими кормами.

\section{Перспективи подальших досліджень.}

Вважаємо за доцільне провести вивчення збереженості поголів'я, санітарно-гігієнічного стану приміщень і технологічного обладнання для подачі кормосумішей та особливості поведінки свиней за використання різного типу корму в період відгодівлі.

\section{Список використаної літератури:}

1. Березовский Н. Д., Почерняев Ф. К., Коротков В. А. Методика моделирования индексов для использования их в селекции свиней. Методы улучшения процессов селекции, разведения и воспроизводства свиней (методические указания). М., 1986. С. 3-14.

2. Вдовіченко Ю. В., Нечмілов, В. М., Повод, М. Г. Продуктивність поросят за сухого, вологого та рідкого типу годівлі на дорощуванні. Вісник Полтавської державної аграрної академії. 2018. Вип. 3, С. $106-109$. https://doi.org/10.31210/visnyk2018.03.15

3. Князев К. И. Интенсивный мясной откорм свиней. М: Колос, 1979. С. 222.

4. Лесной, В. Особенности селекционно-племенной работы с породами свиней в ООО «Фридом Фарм Бекон». Аграрний тиждень. 2015. Вип. 19, С. 13. https://a7d.com.ua/tvarinnictvo/1457-osobennosti-selekcionno-plemennoj-raboty-s.html

5. Михалко О. Г. Відгодівельні якості свиней ірландського походження за різного типу годівлі. Вісник Сумського національного аграрного університету. Серія "Тваринництво". 2020. Вип. 3(42), http://repo.snau.edu.ua/bitstream/123456789/8720/1/7.pdf

6. Повод М. Г., Іжболдина О. О, Нечмилов В. Н., Михалко О.Г., Жижка С. В. Сезонна продуктивність гібридного молодняку свиней за різних типів годівлі. Вісник Сумського національного аграрного університету. Серія "Тваринництво". 2018. Вип. 2 2(34), $2 . \quad$ C. 194-200. bin/irbis_nbuv/cgiirbis_64.exe?C21COM=2\&I21DBN=UJRN\&P21DBN=UJRN\&IMAGE_FILE_DOWNLOAD=1\&Image_file_name=PD 
F/Vsna_tvar_2018_2_46.pdf

7. Рибалко В. П., Березовський М. Д., Богданов Г. А. Сучасні методики досліджень у свинарстві. Полтава, 2005. С. 228.

8. Самсонова О. Е., Бабушкин В. А. Воспроизводительные, откормочные и мясные качества свиней в зависимости от условий кормления и генотипа животных в условиях центрально-чернозёмной зоны. Тамбов:Консалтинговая компания Юком. 2019. С. 116 [Електронний ресурс]. - Режим доступу: https:/lukonf.com/doc/mon.2019.10.02.pdf (дата звернення 17.09.2021 p.).

9. Столюк В. Нові підходи в годівлі свиней. Ефективне свинарство. 2010. Вип. 4., С. 33-35. https://agro.press/storage/journal/56/parts/691/e04bb9ac2b63df6ad84b6e801dcceed4.pdf

10. Тимко В. В. Типи годівлі свиней, їх переваги та недоліки. Матеріали Міжнародної студентської науково-практичної конференції «Наукові дослідження молоді у вирішенні актуальних проблем аграрного сектора України». 2012. С. 52-57. http://ela.nati.org.ua:8080/bitstream/123456789/37/1/v.tymko\%20typy_godivli.pdf

11. Халак В. І., Грабовська О. С. Комплексна оцінка відгодівельних і м'ясних якостей молодняку свиней універсального напряму продуктивності та деякі їх інтер'єрні особливості. Науково-технічний бюлетень Державного науково-дослідного контрольного інституту ветеринарних препаратів та кормових добавок і Інституту біології тварин. 2020. Вип. 2, С. 205-212. https://doi.org/10.36359/scivp.2020-21-2.27

12. Чернєв В. Тваринництво. Годівля насухо. Альтернатива. [Електронний ресурс]. - Режим доступу: https://altua.com/blog/tvarinnictvo-godivlya-nasukho (дата звернення 17.09.2021р.).

13. Blem, N., 2018. New pig farm with liquid feeding. Skiold group. veb-sait. URL: https://skiold.com/news/new-pig-farm-withliquid-feeding (date of request17.09.2021)

14. Brooks, P., Beal, J., Niven, S., 2001. Liquid feeding of pigs: potential for reducing environmental impact and for improving productivity and food safety. Recent Advances in Animal Nutrition in Australia. Vol. 13, pp. 49-63. https://www.researchgate.net/publication/285035317_Liquid_feeding_of_pigs_potential_for_reducing_environmental_impact_and_fo r_improving_productivity_and_food_safety

15. Buragohain, R., Bibeka, N. S., Arup, K. S., Bhuyan, R., Dowarah, R., Roychaudhury, R. and Bora, A., 2019. Dry Vs. Liquid Feeding: Growth Performance, Nutrient Digestibility and Economics in Large White Yorkshire (LWY) Grower-Finisher Pigs. Int.J.Curr.Microbiol.App.Sci., Vol. 8(8), pp. 2019-2025. https://doi.org/10.20546/ijcmas.2019.808.235

16. Carcò, G., Gallo, L., Dalla Bona, M., Latorre, M. A., Fondevila, M. and Schiavon, S., 2018. The influence of feeding behaviour on growth performance, carcass and meat characteristics of growing pigs. PLoS One., issue 13(10):e0205572. doi: 10.1371/journal.pone.0205572. PMID: 30321211; PMCID: PMC6188860.

17. Chae, B. J., 2000. Impacts of wet feeding of diets on growth and carcass traits in pigs. J. Appl. Anim. Res., issue 17, pp. 81-96. https://doi.org/10.1080/09712119.2000.9706293

18. Davies, I., 2015. Liquid-feeding pigs ups finish weight, but lowers kill-out rates. Farmers weekly. veb-sait. URL: https://www.fwi.co.uk/livestock/liquid-feeding-pigs-ups-finish-weight-lowers-kill-rates (date of request17.09.2021)

19. Elkmann, A. and Bärlein, N., 2001. Dry feeding and liquid feeding in pig rearing. Big Datchman. veb-sait. URL: https://www.bigdutchman.com/en/pig-production/news/detail/dry-feeding-and-liquid-feeding-in-pig-rearing/ of request17.09.2021)

20. Han, Y., Thacker, P.A. and Yang, J., 2006. Effects of the Duration of Liquid Feeding on Performance and Nutrient Digestibility in Weaned Pigs. Asian-Aust. J. Anim. Sci., Vol 19, issue 3, pp. $396-401$. https://pdfs.semanticscholar.org/ad9a/63066870dd50d499327fed776d4054adaf7d.pdf

21. Hurst, D, Clarke, L. and Lean, I., 2008. Effect of liquid feeding by different water-to-feed ratios on the growth performance of growing-finishing pigs. Animal : an international journal of animal bioscience. issue. 2, pp. $1297-1303$. https://doi.org/10.1017/S175173110800253X

22. Hurst, D., Juniper, D., Clark, L., Litten-Brown, J., Corson, A. and Lean, I., 2020. Effect of liquid feeding at different waterto-feed ratios on the morphological adaptations in the gastrointestinal tract of growing pigs. Journal of Food Nutrition and Agriculture, issue 3, pp. 1-8. https://doi.org/10.21839//fna.2020.v3.314

23. Kim, J., 2011.Test for improving pig feed. Pig Progress Piglet Feeding Special, issue 27(4). https://issuu.com/pigprogress/docs/04-2011

24. Kouhei, M., Kazuo, H. and Seigo, I., 1996. Effects of Wet/Dry Feeding for Finishing Pigs on Growth, Feed Conversion and Carcass Quality. Journal of the Japanese Pig Society, issue 33, pp. 5-13. https://doi.org/10.5938/youton.33.5

25. Lawlor, P. G., Lynch, P. B., Gardiner, G. E., Caffrey, P. J. and O'Doherty, J. V., 2002. Effect of liquid feeding weaned pigs on growth performance to harvest. J. Anim. Sci., issue 80, pp. 1725-1735. https://doi.org/10.2527/2002.8071725x

26. Liquid vs Dry Feeding. The pig site. veb-sait. URL: https://www.thepigsite.com/articles/liquid-vs-dry-feeding [date of request17.09.2021]

27. McCracken, B. A., Spurlock, M. E., Roos, M. A., Zuckermann, F. A. and Gaskins, H. R., 1999. Biochemical and Molecular Action of Nutrients Weaning Anorexia May Contribute to Local Inflammation in the Piglet Small Intestine. J. Nutr., issue 129, pp. 613-619. https://doi.org/10.1093/jn/129.3.613

28. Moon, J. S., Kwon, I. K. and Chae, B. J., 2004. Effects of Wet Feeding of Diets with or without Food Waste on Growth Performance and Carcass Characteristics in Finishing Pigs. Asian-Aust. J. Anim. Sci., Vol. 17, issue 4, pp. 504-510. https://www.animbiosci.org/upload/pdf/17_80.pdf

29. Myers, A. J., Goodband, R. D., Tokach, M. D., Dritz, S. S., DeRouchey, J. M. and Nelssen, J. L., 2013. The effects of diet 
form and feeder design on the growth performance of finishing pigs1,2. Journal of Animal Science, issue 91(7), pp. 3420-3428. https://doi.org/10.2527/jas.2012-5612

30. Nitikanchana, S., Dritz ,S. S., Tokach, M. D., Goodband, R. D., Derouchy, J. M. and Nielsen, J. L., 2012. Meta-analysis on pros and cons of wet-dry feeders. IPVS Congress. Pig progress. veb-sait. URL: https://www.pigprogress.net/Finishers/Articles/2012/12/Meta-analysis-on-pros-and-cons-of-wet-dry-feeders-1120060W/ (date of request17.09.2021)

31. O'Meara, F. M., Gardiner, G. E., Clarke, D., Cummins, W., O'Doherty, J. V. and Lawlor, P. G., 2020. Microbiological assessment of liquid feed for finisher pigs on commercial pig units. Journal of Applied Microbiology, Vol. 130, Issue 2, pp. 356-369. https://doi.org/10.1111/jam.14785

32. O'Meara, F. M., Gardiner, G. E., O'Doherty, J. V. and Lawlor, P. G., 2020. The effect of feed form and delivery method on feed microbiology and growth performance in grow-finisher pigs. J Anim Sci., issue 98(3):skaa021. https://doi.org/10.1093/jas/skaa021.

33. Peadar, L. and O' Meara, F., 2018. Comparison of Dry, Wet/Dry and Wet feeding for Finisher pigs. Teagasc, Pig Development Department. veb-sait. URL: https://www.teagasc.ie/publications/2018/comparison-of-dry-wetdry-and-wet-feeding-forfinisher-pigs.php (date of request17.09.2021)

34. Pedersen, C. and Stein, H. H., 2010. Effects of liquid and fermented liquid feeding on energy, dry matter, protein and phosphorus digestibility by growing pigs, Livestock Science, Vol. 134, Issues 1(3), pp. 59-61, https://doi.org/10.1016/j.livsci.2010.06.097.

35. Plumed-Ferre, C. A. and Wright, V., 2009. Fermented pig liquid feed: nutritional, safety and regulatory aspects. Journal of Applied Microbiology. Vol. 106, Issue 2. pp. 351-368. https://doi.org/10.1111/j.1365-2672.2008.03938.x

36. Sol, C., Castillejos, L., López-Vergé, S., Muns, R. and Gasa, J., 2019. Effects of the Feed: Water Mixing Proportion on Diet Digestibility of Growing Pigs. Animals, issue 9, p. 791; https://doi.org/10.3390/ani9100791

37. Sulabo, R. C., Groesbeck, C. N., Benz, J. M., McKilligan, D., Goodband, R., Tokach D., Michael D., DeRouchey, J. M., Nelssen, J. L., and Dritz, S. S., 2006. Effects of a liquid (neolac1) and dry feed combination fed in varying durations on weanling pig performance, Kansas Agricultural Experiment Station Research Reports, Vol. 0, issue. 10. https://doi.org/10.4148/2378-5977.6991

38. Zhang, S, Yoo, D. H., Ao, X., Kim, I. H., 2020. Effects of dietary probiotic, liquid feed and nutritional concentration on the growth performance, nutrient digestibility and fecal score of weaning piglets. Asian-Australasian Journal of Animal Sciences, issue 33(10), p. 1617. https://doi.org/10.5713/ajas.19.0473

39. Zoric, M., Johansson, S. E. and Wallgren, P., 2015. Behaviour of fattening pigs fed with liquid feed and dry feed. Porc Health Manag, Vol 1, issue14. https://doi.org/10.1186/s40813-015-0009-7

\section{References:}

1. Berezovskiy, N. D., Pochernyaev, F. K.and Korotkov, V. A.,1986. Metodika modelirovaniya indeksov dlya ispolzovaniya in v selektsii sviney [Methods for modeling indices for use in pig breeding]. Metodyi uluchsheniya protsessov selektsii, razvedeniya $i$ vosproizvodstva sviney (metodicheskie ukazaniya). M., pp. 3-14.

2. Vdovichenko, Yu. V., Nechmilov, V. M. and Povod, M. H., 2018. Produktyvnist porosiat za sukhoho, volohoho ta ridkoho typu hodivli na doroshchuvanni [Productivity of piglets in dry, wet and liquid type of feeding on rearing.]. Visnyk Poltavskoi derzhavnoi ahrarnoi akademii. issue 3, pp. 106-109. https://doi.org/10.31210/visnyk2018.03.15

3. Knyazev, K. I.,1979. Intensivnyiy myasnoy otkorm sviney [Intensive meat fattening of pigs]. M: Kolos. p. 222.

4. Lesnoy, V., 2015. Osobennosti selektsionno-plemennoy rabotyi s porodami sviney v 000 «Fridom Farm Bekon» [Features of selection and breeding work with pig breeds in Freedom Farm Bacon LLC.]. Agrarniy tizhden, issue 19, p. 13. https://a7d.com.ua/tvarinnictvo/1457-osobennosti-selekcionno-plemennoj-raboty-s.html

5. Mykhalko, O. G., 2020. Vidhodivelni yakosti svynei irlandskoho pokhodzhennia za riznoho typu hodivi [Feeding qualities of pigs of Irish origin for different types of feeding.]. Visnyk Sumskoho natsionalnoho ahrarnoho universytetu. Seriia "Tvarynnytstvo", issue 3(42), pp. 51-57. http://repo.snau.edu.ua/bitstream/123456789/8720/1/7.pdf

6. Povod M. H., Izhboldyna O. O, Nechmylov V. N., Mykhalko O.H., Zhyzhka S. V., 2018. Sezonna produktyvnist hibrydnoho molodniaku svynei za riznykh typiv hodivli [Seasonal productivity of hybrid young pigs for different types of feeding]. Visnyk Sumskoho natsionalnoho ahrarnoho universytetu. Seriia "Tvarynnytstvo", issue 2(34), pp. 194-200. http://irbisnbuv.gov.ua/cgi-

bin/irbis_nbuv/cgiirbis_64.exe?C21COM=2\&|21DBN=UJRN\&P21DBN=UJRN\&IMAGE_FILE_DOWNLOAD=1\&Image_file_name=PD F/Vsna_tvar_2018_2_46.pdf

7. Rybalko, V. P., Berezovskyi, M. D. and Bohdanov, H. A., 2005. Suchasni metodyky doslidzhen u svynarstvi [Modern research methods in pig breeding.]. Poltava, p. 228.

8. Samsonova, O. E.and Babushkin, V. A., 2019. Vosproizvoditelnyie, otkormochnyie i myasnyie kachestva sviney v zavisimosti ot usloviy kormleniya i genotipa zhivotnyih v usloviyah tsentralno-chernozYomnoy zonyi. Tambov:Konsaltingovaya kompaniya Yukom. 2019. p. 116 [Elektronnyi resurs]. - Rezhym dostupu:https://ukonf.com/doc/mon.2019.10.02.pdf (data zvernennia 17.09.2021)

9. Stoliuk, V., 2010. Novi pidkhody v hodivli svynei [New approaches in feeding pigs]. Efektyvne svynarstvo, issue 4, pp. 33-35. https://agro.press/storage/journal/56/parts/691/e04bb9ac2b63df6ad84b6e801dcceed4.pdf

10. Tymko, V. V., 2012. Typy hodivli svynei, yikh perevahy ta nedoliky [Types of feeding pigs, their advantages and disadvantages.]. Materialy Mizhnarodnoi studentskoi naukovo-praktychnoi konferentsii «Naukovi doslidzhennia molodi u vyrishenni aktualnykh problem ahrarnoho sektora Ukrainy», pp. 
http://ela.nati.org.ua:8080/bitstream/123456789/37/1/v.tymko\%20typy_godivli.pdf

11. Khalak, V. I. and Hrabovska, O. S., 2020. Kompleksna otsinka vidhodivelnykh i miasnykh yakostei molodniaku svynei universalnoho napriamu produktyvnosti ta deiaki yikh interierni osoblyvosti [Comprehensive assessment of fattening and meat qualities of young pigs of the universal direction of productivity and some of their interior features.]. Naukovo-tekhnichnyi biuleten Derzhavnoho naukovo-doslidnoho kontrolnoho instytutu veterynarnykh preparativ ta kormovykh dobavok i Instytutu biolohii tvaryn, issue 2, pp. 205-212. https://doi.org/10.36359/scivp.2020-21-2.27

12. Cherniev, V., 2021. Tvarynnytstvo. Hodivlia nasukho. Alternatyva. [Elektronnyi resurs]. - Rezhym dostupu: https://altua.com/blog/tvarinnictvo-godivlya-nasukho (data zvernennia 17.09.2021).

13. Blem, N., 2018. New pig farm with liquid feeding. Skiold group. veb-sait. URL: https://skiold.com/news/new-pig-farm-withliquid-feeding (date of request17.09.2021)

14. Brooks, P., Beal, J., Niven, S., 2001. Liquid feeding of pigs: potential for reducing environmental impact and for improving productivity and food safety. Recent Advances in Animal Nutrition in Australia. Vol. 13, pp. 49-63. https://www.researchgate.net/publication/285035317_Liquid_feeding_of_pigs_potential_for_reducing_environmental_impact_and_fo r_improving_productivity_and_food_safety

15. Buragohain, R., Bibeka, N. S., Arup, K. S., Bhuyan, R., Dowarah, R., Roychaudhury, R. and Bora, A., 2019. Dry Vs. Liquid Feeding: Growth Performance, Nutrient Digestibility and Economics in Large White Yorkshire (LWY) Grower-Finisher Pigs. Int.J.Curr.Microbiol.App.Sci., Vol. 8(8), pp. 2019-2025. https://doi.org/10.20546/ijcmas.2019.808.235

16. Carcò, G., Gallo, L., Dalla Bona, M., Latorre, M. A., Fondevila, M. and Schiavon, S., 2018. The influence of feeding behaviour on growth performance, carcass and meat characteristics of growing pigs. PLoS One., issue 13(10):e0205572. doi: 10.1371/journal.pone.0205572. PMID: 30321211; PMCID: PMC6188860.

17. Chae, B. J., 2000. Impacts of wet feeding of diets on growth and carcass traits in pigs. J. Appl. Anim. Res., issue 17, pp. 81-96. https://doi.org/10.1080/09712119.2000.9706293

18. Davies, I., 2015. Liquid-feeding pigs ups finish weight, but lowers kill-out rates. Farmers weekly. veb-sait. URL: https://www.fwi.co.uk/livestock/liquid-feeding-pigs-ups-finish-weight-lowers-kill-rates (date of request17.09.2021)

19. Elkmann, A. and Bärlein, N., 2001. Dry feeding and liquid feeding in pig rearing. Big Datchman. veb-sait. URL: https://www.bigdutchman.com/en/pig-production/news/detail/dry-feeding-and-liquid-feeding-in-pig-rearing/ (date of request17.09.2021)

20. Han, Y., Thacker, P.A. and Yang, J., 2006. Effects of the Duration of Liquid Feeding on Performance and Nutrient Digestibility in Weaned Pigs. Asian-Aust. J. Anim. Sci., Vol 19, issue 3, pp. 396-401. https://pdfs.semanticscholar.org/ad9a/63066870dd50d499327fed776d4054adaf7d.pdf

21. Hurst, D, Clarke, L. and Lean, I., 2008. Effect of liquid feeding by different water-to-feed ratios on the growth performance of growing-finishing pigs. Animal : an international journal of animal bioscience. issue. 2, pp. 1297-1303. https://doi.org/10.1017/S175173110800253X

22. Hurst, D., Juniper, D., Clark, L., Litten-Brown, J., Corson, A. and Lean, I., 2020. Effect of liquid feeding at different waterto-feed ratios on the morphological adaptations in the gastrointestinal tract of growing pigs. Journal of Food Nutrition and Agriculture, issue 3, pp. 1-8. https://doi.org/10.21839//fna.2020.v3.314

23. Kim, J., 2011.Test for improving pig feed. Pig Progress Piglet Feeding Special, issue 27(4). https://issuu.com/pigprogress/docs/04-2011

24. Kouhei, M., Kazuo, H. and Seigo, I., 1996. Effects of Wet/Dry Feeding for Finishing Pigs on Growth, Feed Conversion and Carcass Quality. Journal of the Japanese Pig Society, issue 33, pp. 5-13. https://doi.org/10.5938/youton.33.5

25. Lawlor, P. G., Lynch, P. B., Gardiner, G. E., Caffrey, P. J. and O'Doherty, J. V., 2002. Effect of liquid feeding weaned pigs on growth performance to harvest. J. Anim. Sci., issue 80, pp. 1725-1735. https://doi.org/10.2527/2002.8071725x

26. Liquid vs Dry Feeding. The pig site. veb-sait. URL: https://www.thepigsite.com/articles/liquid-vs-dry-feeding [date of request17.09.2021]

27. McCracken, B. A., Spurlock, M. E., Roos, M. A., Zuckermann, F. A. and Gaskins, H. R., 1999. Biochemical and Molecular Action of Nutrients Weaning Anorexia May Contribute to Local Inflammation in the Piglet Small Intestine. J. Nutr., issue 129, pp. 613-619. https://doi.org/10.1093/in/129.3.613

28. Moon, J. S., Kwon, I. K. and Chae, B. J., 2004. Effects of Wet Feeding of Diets with or without Food Waste on Growth Performance and Carcass Characteristics in Finishing Pigs. Asian-Aust. J. Anim. Sci., Vol. 17, issue 4, pp. 504-510. https://www.animbiosci.org/upload/pdf/17_80.pdf

29. Myers, A. J., Goodband, R. D., Tokach, M. D., Dritz, S. S., DeRouchey, J. M. and Nelssen, J. L., 2013. The effects of diet form and feeder design on the growth performance of finishing pigs1,2. Journal of Animal Science, issue 91(7), pp. 3420-3428. https://doi.org/10.2527/jas.2012-5612

30. Nitikanchana, S., Dritz ,S. S., Tokach, M. D., Goodband, R. D., Derouchy, J. M. and Nielsen, J. L., 2012. Meta-analysis on pros and cons of wet-dry feeders. IPVS Congress. Pig progress. veb-sait. URL: https://www.pigprogress.net/Finishers/Articles/2012/12/Meta-analysis-on-pros-and-cons-of-wet-dry-feeders-1120060W/ (date of request17.09.2021)

31. O'Meara, F. M., Gardiner, G. E., Clarke, D., Cummins, W., O'Doherty, J. V. and Lawlor, P. G., 2020. Microbiological assessment of liquid feed for finisher pigs on commercial pig units. Journal of Applied Microbiology, Vol. 130, issue 2, pp. 356-369. https://doi.org/10.1111/jam.14785

32. O'Meara, F. M., Gardiner, G. E., O'Doherty, J. V. and Lawlor, P. G., 2020. The effect of feed form and delivery method 
on feed microbiology and growth performance in grow-finisher pigs. $J$ Anim Sci., issue 98(3):skaa021. https://doi.org/10.1093/jas/skaa021.

33. Peadar, L. and O' Meara, F., 2018. Comparison of Dry, Wet/Dry and Wet feeding for Finisher pigs. Teagasc, Pig Development Department. veb-sait. URL: https://www.teagasc.ie/publications/2018/comparison-of-dry-wetdry-and-wet-feeding-forfinisher-pigs.php (date of request17.09.2021)

34. Pedersen, C. and Stein, H. H., 2010. Effects of liquid and fermented liquid feeding on energy, dry matter, protein and phosphorus digestibility by growing pigs, Livestock Science, Vol. 134, Issues 1(3), pp. 59-61, https://doi.org/10.1016/j.livsci.2010.06.097.

35. Plumed-Ferre, C. A. and Wright, V., 2009. Fermented pig liquid feed: nutritional, safety and regulatory aspects. Journal of Applied Microbiology. Vol. 106, Issue 2. pp. 351-368. https://doi.org/10.1111/j.1365-2672.2008.03938.x

36. Sol, C., Castillejos, L., López-Vergé, S., Muns, R. and Gasa, J., 2019. Effects of the Feed: Water Mixing Proportion on Diet Digestibility of Growing Pigs. Animals, issue 9, p. 791; https://doi.org/10.3390/ani9100791

37. Sulabo, R. C., Groesbeck, C. N., Benz, J. M., McKilligan, D., Goodband, R., Tokach D., Michael D., DeRouchey, J. M., Nelssen, J. L., and Dritz, S. S., 2006. Effects of a liquid (neolac1) and dry feed combination fed in varying durations on weanling pig performance, Kansas Agricultural Experiment Station Research Reports, Vol. 0, issue. 10. https://doi.org/10.4148/2378-5977.6991

38. Zhang, S, Yoo, D. H., Ao, X., Kim, I. H., 2020. Effects of dietary probiotic, liquid feed and nutritional concentration on the growth performance, nutrient digestibility and fecal score of weaning piglets. Asian-Australasian Journal of Animal Sciences, issue 33(10), p. 1617. https://doi.org/10.5713/ajas.19.0473

39. Zoric, M., Johansson, S. E. and Wallgren, P., 2015. Behaviour of fattening pigs fed with liquid feed and dry feed. Porc Health Manag, Vol 1, issue14. https://doi.org/10.1186/s40813-015-0009-7

Mykhalko Oleksandr Hryhorovych, graduate student

Sumy National Agrarian University (Sumy, Ukraine)

Dependence of Danish pigs fattening qualities on the type of feeding

The aim of the article was to investigate the dependence of fattening qualities of Danish pigs on the type of feeding. In order to determine the impact of feed type on the results of fattening pigs, a research and production experiment was conducted on the basis of an industrial pig farm in the Central steppe of Ukraine, after which the data were summarized, analyzed and described in this manuscript. Fattening of young pigs was carried out in two technological groups including 195 heads in the premises of fattening farm of one enterprise, where the conditions of pigs keeping were identical, except the type of feed mixtures in the rations. The pigs of the control group were fattened with dry feed, and the pigs of the experimental group were fattened with liquid. The initial average live weight and age at fattening were the same in animals of both groups, however, at the end of the fattening period at age of 88 days, pigs consuming liquid feed significantly outperformed peers on dry feed by $6.9 \mathrm{~kg}$ or $6.1 \%(p<0.001)$. It was also found that the growth intensity was higher in animals of the experimental group on $87.1 \mathrm{~g}$ or $9.4 \%$ - by average daily gain, on $8.3 \mathrm{~kg}$ or $8.5 \%$ by absolute gain, on $4.0 \%$ - by relative growth. Significantly faster on 5.6 days or $3.8 \%$ reached a weight of $100 \mathrm{~kg}$ of pigs for fattening with liquid feed, relative to analogues for fattening dry. No significant effect of feed type on feed conversion rate in both groups was found. A study of the fattening qualities of pigs on a set of fattening qualities, calculated using the evaluation index showed that the animals for the use of liquid feed scored a higher score of 6.1 or $17.8 \%$ compared to analogues who were given dry feed. Thus, fattening young pigs of Danish origin using a liquid type of feeding is more efficient and gives higher results in a shorter time at the same feed costs compared to fattening with dry feed.

Key words: fattening pigs, fattening qualities, type of feed,, liquid and dry feed, type of feeding

Дата надходження до редакції: 23.09.2021 р. 